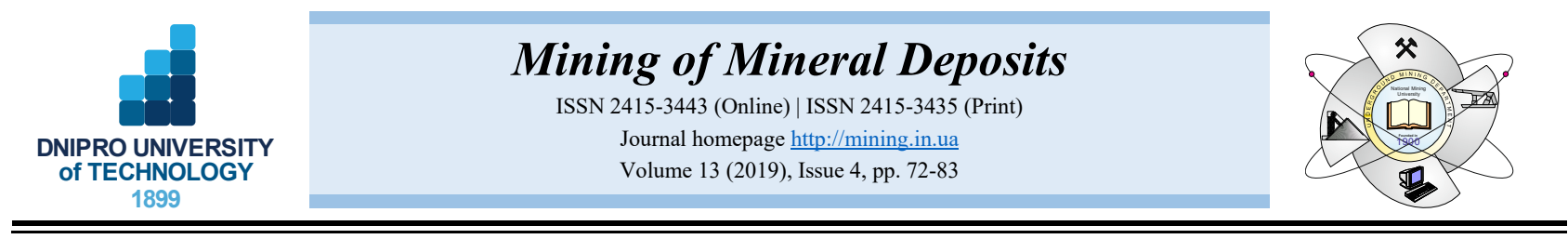

UDC 622.833:622.26

https://doi.org/10.33271/mining13.04.072

\title{
IMPLEMENTATION OF PROBABILISTIC APPROACH TO ROCK MASS STRENGTH ESTIMATION WHILE EXCAVATING THROUGH FAULT ZONES
}

\author{
D. Babets ${ }^{1 *}$, O. Sdvyzhkova ${ }^{1}$, O. Shashenko ${ }^{1}$, K. Kravchenko ${ }^{1}$, E.C. Cabana ${ }^{2}$ \\ ${ }^{1}$ Dnipro University of Technology, Dnipro, Ukraine \\ ${ }^{2}$ University of St. Augustine, Arequipa, Peru \\ *Corresponding author: e-mail babets.d.v@nmu.one, tel.+380955999617
}

\begin{abstract}
Purpose. The paper addresses the rock mass state estimation while excavating a cross-heading through the area of regional fault "Bohdanivskyi" based on probabilistic approach to assessing the rock strength.

Methods. The boundaries and fault zone extension are specified based on geological service database. This hazardous fault area has been confirmed, and the expected water inflow and methane emission have been identified based on the probe holes drilled ahead of the advancing face. To assess the strength of rocks, the statistical strength theory is used. Numerical simulation is performed using finite element method that is well-tested in geomechanical problems.

Findings. The technique of rock mass strength estimation using structural factor based on statistical strength theory has been implemented to improve the adequacy of mathematical modeling. Numerical simulation of geomechanical processes based on finite element method and Hoek-Brown failure criterion is carried out. The changes of rock stress-strain state while excavating the cross-heading through various sites of the fault zone are determined depending on the level of rock disintegration.
\end{abstract}

Originality. New regularities of rock mass behavior within the fault area are determined based on developed technique of rock strength assessment considering the rock mass disintegration and watering.

Practical implications. Estimation of rock failure has resulted in designing the combination of support systems comprising metal sets, rockbolts and shotcrete.

Keywords: fault zone, support design, structural factor, rock joints, rock mass strength

\section{INTRODUCTION}

Western Donbas coal deposit is located in Dnipropetrovsk region of Ukraine and covers an area of $12000 \mathrm{~km}^{2}$. It is one of the main suppliers of coal in Ukraine. Numerous faults are located in the western part of the deposit. Mining activity is carried out under complicated geological conditions caused by poor and jointed rocks (Sdvyzhkova, Babets, Kravchenko, \& Smirnov, 2015). The main mining enterprise in Western Donbass is "DTEK Pavlohradvuhillia" PJS Company. Despite unfavorable conditions, the company introduces new technologies as an effort to increase production efficiency (Pivnyak \& Shashenko, 2015). Intensive coal mining not only results in increasing mining depth, but also requires expanding the mine field boundaries and involving conserved coal reserves. These problems are associated with excavating through fault zones outlining the mine field.

In geomechanics, such problems as fracturing, heterogeneity and fault zones are solved by introducing cor- rection factors that reduce the design strength. In particular, the so called structural factor $\left(k_{c}\right)$ is regulated by normative documents and is widely used by mining engineers in Ukraine (SOU 10.1-00185790-002-2005, 2005). This factor was introduced as the ratio of heterogeneous rock mass strength characteristic and a value of strength characteristic obtained during laboratory testing of rock specimens. A quantitative estimate of this factor can be made on the basis of a probability model of rock mass strength. According to the probability approach rock mass is treated as an aggregate comprising structural elements whose physical and mechanical properties are random values distributed according to a certain probability law (Hahn \& Shapiro, 1994).

On the other hand, rating systems are widely used to estimate the design rock mass strength. For instance, Hoek's Geological Strength Index (GSI) based on geological parameters is well proved to adjust parameters of jointed rock to the values appropriate in situ (Marinos \& Hoek, 2000).

(C) 2019. D. Babets, K. Kravchenko, O. Sdvyzhkova, O. Shashenko, E.C. Cabana. Published by the Dnipro University of Technology on behalf of Mining of Mineral Deposits. This is an Open Access article distributed under the terms of the Creative Commons Attribution License (http://creativecommons.org/licenses/by/4.0/),

which permits unrestricted reuse, distribution, and reproduction in any medium, provided the original work is properly cited. 
Both approaches were used to determine the design rock mass strength for numerical simulation of the stressstrain state while excavating the cross-heading through the fault zone, which resulted in designing the combination of support systems comprising metal sets, rockbolts and shotcrete.

\section{METHODS}

\subsection{Geological profile of regional fault "Bohdanivskyi"}

As the thickness of the coal seams varies from 0.1 to $1.5 \mathrm{~m}$, they can be classified as "thin seams" (Nahornyi, Nahornyi, \& Prykhodchenko, 2005). The distance between the seams varies from 4.6 up to $40-60 \mathrm{~m}$. The depth of coal seam below ground surface varies from 50 up to $900 \mathrm{~m}$. The coal formation is characterized by monoclinal bedding with an angle of inclination between 1 to $5^{\circ}$.

According to the mine survey service, the fault "Bohdanivskyi" has north-western strike that coincides with the strike of the lower carboxylic strata. The fault has a dip angle from 45 to $60^{\circ}$ throw height $H=270 \mathrm{~m}$ (Fig. 1). The width of the disturbed zones near the fault reaches up to $85 \mathrm{~m}$.

Fault zones always present special challenges while excavating because rock displacements can progress dramatically due to excessive overloading (Dychkovskyi et al., 2018; Nadutyi, Tytov, \& Cheberiachko, 2018; Tytov, Haddad, \& Sukhariev, 2019) ground water inflows (Zhang, Jiang, Zhou, Yang, \& Xiao, 2013; Bomba et al., 2018) and gas drainage (Law et al., 1998; Bondarenko, Kharin, Antoshchenko, \& Gasyuk, 2013). Recently, there has not been any experience in a roadway driving through such zones in terms of Western Donbas geological conditions (Khalymendyk \& Baryshnikov, 2018). That is why designing an appropriate support system as well as a sequence of excavating and support installing to provide the long-term stability of underground structure is a major issue.

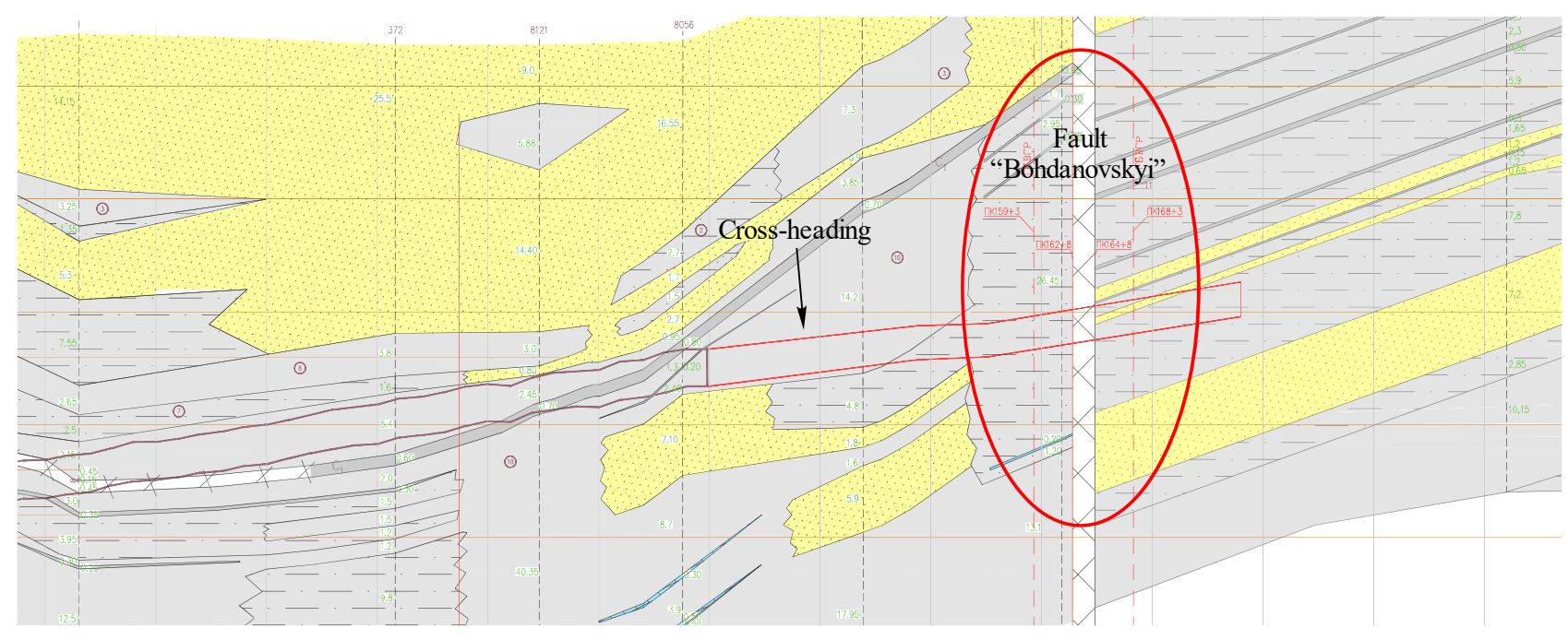

Figure 1. Parameters of the fault "Bohdanivskyi"

Development of a new site for reserved coal mining started with excavating a cross-heading through the fault "Bohdanivskyi" from the actual coal field of the "Samarska" mine to the reserved field of the "ZakhidnoDonbaska" mine. The cross-heading of an arched shape $5.14 \mathrm{~m}$ wide and $4.1 \mathrm{~m}$ high is being excavated through weak rock mass represented by siltstones, mudstone and sandstone. Mudstones and siltstones of Western Donbass are classified as poor and unstable rocks according to the classification adopted in Ukraine (Prykhodchenko, Sdvyzhkova, Khomenko, \& Tykhonenko, 2016).

A distinctive feature of the coal deposit geological structure is that coal is strong and ductile with compressive strength of $25-35 \mathrm{MPa}$, while the floor and the roof are composed of weak jointed rocks with compressive strength $20-25 \mathrm{MPa}$. When exposed to water they lose $50-80 \%$ of their strength. Floor heaving often occurs during excavation (Solodyankin, Hryhoriev, Dudka, \& Mashurka, 2017).

The fault zone is considered to be the structure that is heavily jointed and disintegrated. Hoek, Wood and Shah (Hoek, 2002) note that fault zones are generally less permeable than the surrounding rock mass. There is a chance that a large volume of water may be trapped behind the face. The weak fault materials and the presence of water can result in squeezing or flowing ground conditions.

Taking into account the challenges mentioned above, the entire heading route was divided into sections, depending on the fault zone proximity (Fig. 2).

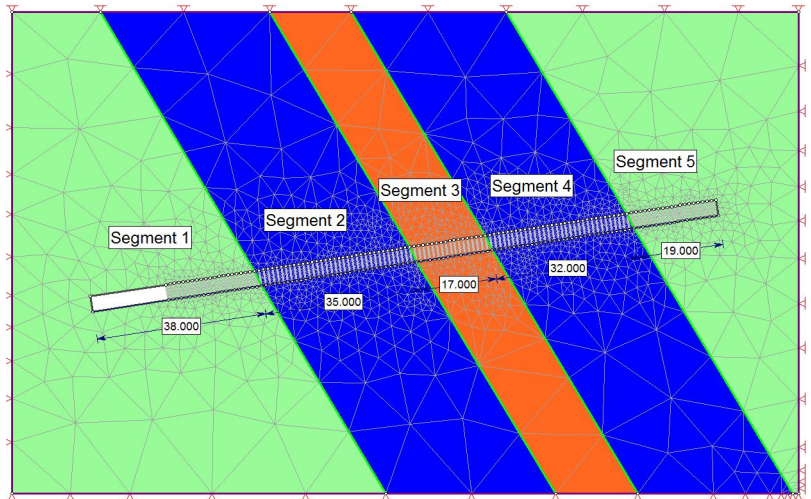

Figure 2. Dividing the cross-heading route into sections with different rock properties 
Segment 3 is the most dangerous excavating site (fault zone) that is $17 \mathrm{~m}$ wide. Segment 2 and Segment 4 are located before the fault zone and after it. These sites are 39 and $32 \mathrm{~m}$ wide, and each is a hazardous area as well. Rock state monitoring starts when the crossheading face approaches Segment 1 which is $38 \mathrm{~m}$ wide. This site is not considered hazardous but requires increased attention. Drilling of two probe holes ahead of the advancing face is necessary to specify the fault zone borders. One of the holes, $50 \mathrm{~m}$ long, is drilled into the

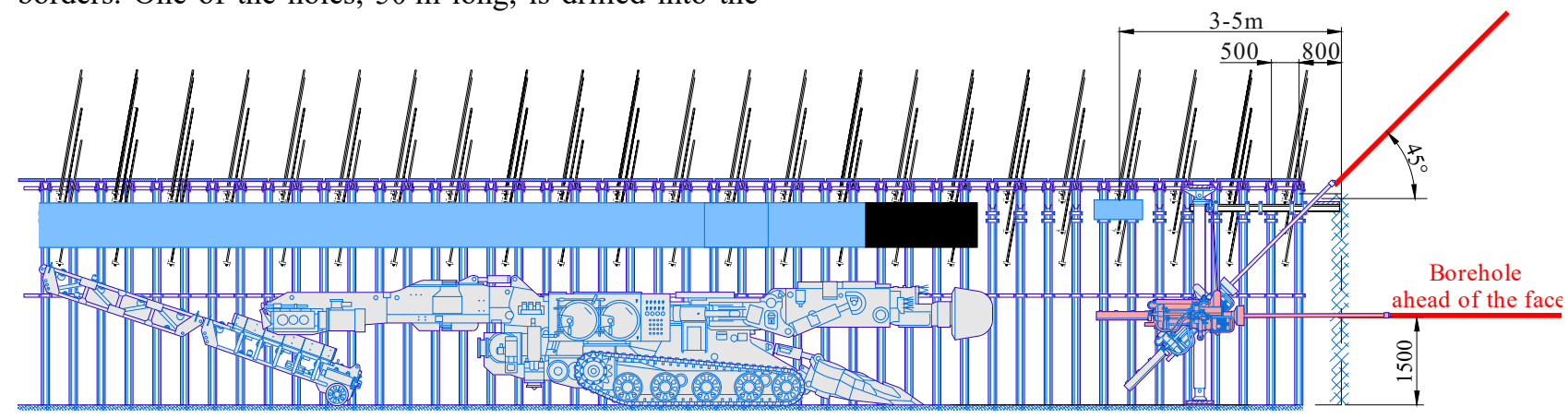

Figure 3. Drilling two probe holes ahead of the advancing face (longitudinal section of the cross-heading)

\subsection{Rock mass mechanical characteristics Estimation}

To predict the rock mass behavior at various stage of excavating, the preliminary numerical simulation should be carried out taking into account all possible changes in rock structure (Vladyko, Kononenko, \& Khomenko, 2012; Pivnyak, Dychkovskyi, Smirnov, \& Cherednichenko, 2013; Pivnyak, Dychkovskyi, Bobyliov, Cabana, \& Smoliński, 2018). To apply adequate mathematical modeling (Shashenko, Gapieiev, Solodyankin, 2009; Olevskyi \& Olevska, 2018) for studying the stress-strain state of surrounding rocks, we need a correct estimation of mechanical properties.

In (Babets, Sdvyzhkova, Larionov, \& Tereshchuk, 2017), the extensive analysis of different approaches to rock heterogeneity and its effect on mechanical properties concerning numerical simulation was carried out. The relationship between structural factor (widely used in Ukraine) and Geological Strength Index was established and considerable influence of discontinuities condition and the type of filler between joints on mechanical properties of a rock mass have been shown.

According to statistical strength theory, the rock mass is considered as a unit comprising different structural elements. The compressive strength of each structural element is supposed to be a random variable $\sigma$ submitted to some probability distribution $F(\sigma)$. In (Babets, 2018), a hypothesis of lognormal distribution of structural elements strength was put forward.

In this case, an expression for structural factor looks like:

$$
k_{c}=\frac{\exp \left(\arg F_{0}(1-p) \cdot \sqrt{\ln \left(\eta^{2}+1\right)}\right)}{\sqrt{\eta^{\prime 2}+1}},
$$

where:

$\eta$ - a variation of a random sample obtained in laboratory compressive strength test; excavation roof at an angle of 450 (Fig. 3). Another hole, $45 \mathrm{~m}$ long, is drilled horizontally in the face center at a distance of $1.5 \mathrm{~m}$ from the excavation floor. Before drilling, the road-heading machine should be pushed back at a distance of $4 \mathrm{~m}$, so that rock drilling machine can be installed. The volume of return water as well as the character of the chippings is monitored during the drilling in order to avoid uncontrolled deformation of the heading and install the support of appropriate capacity. $\arg F_{0}(1-p)$ - an argument of standardized normal distribution function $F_{0}$;

$p-$ a confidence level.

Hence, the structural factor depends on the variation $(\eta)$ that accounts for natural heterogeneity of rocks. According to the research conducted in (Babets, 2018), this variation could be "corrected" to account for the effect of joints.

The distance between joints, their orientation and discontinuity conditions can be taken into account using joints' effect coefficient. This coefficient of $k^{\text {th }}$ order $\left(K_{j}\right)$ corrects initial and central statistic moments of random distribution. It is determined by the expression:

$$
K_{j k}=\frac{l_{t}+l_{0} f^{k}(\alpha)}{l_{t}(1+f(j))+l_{0}},
$$

where:

$f(\alpha)$ - a function that describes orientation of joints' effect (angle $\alpha$ );

$f(j)$ - a function that reflects the decrease of strength due to poor discontinuity surface quality;

$l_{t}-$ a distance between joints in a rock mass;

$l_{0}-\mathrm{a}$ linear size of rock specimen tested under laboratory conditions.

The improved variation of the "corrected" random sample of mechanical characteristic is determined by the expression:

$\eta^{\prime}=\sqrt{\frac{K_{j 2}}{K_{j 1}^{2}}\left(\eta^{2}+1\right)-1}$

Therefore, according to the probabilistic-statistical model based on logarithmic-normal random distribution, the structural factor is obtained by substitution of the "corrected" variation (Eq. 3) in Equation 1. 


\section{RESULTS AND DISCUSSION}

\subsection{Implementation of the probabilistic approach in structural factor calculation}

Lithological composition of the coal seam $\mathrm{C}_{10}{ }^{\mathrm{b}}$ roof and floor is heterogeneous (Sdvyzhkova, Babets, \&
Smirnov, 2014). The geological data and the results of design rock strength estimation for various segments are represented in Tables $1-3$. Discontinuity surveys on borehole cores and in situ observation (Fig. 4) allowed estimating distance between joints, their orientation and discontinuity conditions.

Table 1. Rock mass strength parameters and geological data (Segment 1 \& Segment 5)

\begin{tabular}{lcccccc}
\hline Rock & $\begin{array}{c}\text { Mean value of } \\
\text { intact comp. } \\
\text { strength, } \overline{R_{c}}, \mathrm{MPa}\end{array}$ & $\begin{array}{c}\text { Variation } \\
\text { of random } \\
\text { sample, } \eta\end{array}$ & $f(j)$ & $\begin{array}{c}\text { "Corrected" } \\
\text { variation, } \eta^{\prime}\end{array}$ & $\begin{array}{c}\text { Structural } \\
\text { factor, } k_{c}\end{array}$ & $\begin{array}{c}\text { Rock mass } \\
\text { strength, } \\
R_{c}, \mathrm{MPa}\end{array}$ \\
\hline Claystone & 25 & 0.35 & 0.1 & 0.58 & 0.4 & 10.0 \\
Siltstone & 20 & 0.33 & 0.16 & 0.62 & 0.34 & 6.7 \\
\hline
\end{tabular}

Table 2. Rock mass strength parameters and geological data (Segment 2 \& Segment 4)

\begin{tabular}{lcccccc}
\hline Rock & $\begin{array}{c}\text { Mean value of } \\
\text { intact comp. } \\
\text { strength, } \overline{R_{c}}, \mathrm{MPa}\end{array}$ & $\begin{array}{c}\text { Variation } \\
\text { of random } \\
\text { sample, } \eta\end{array}$ & $f(j)$ & $\begin{array}{c}\text { "Corrected”, } \\
\text { variation, } \eta^{\prime}\end{array}$ & $\begin{array}{c}\text { Structural } \\
\text { factor, } k_{c}\end{array}$ & $\begin{array}{c}\text { Rock mass } \\
\text { strength, } \\
R_{c}, \mathrm{MPa}\end{array}$ \\
\hline Claystone & 25 & 0.35 & 0.35 & 0.89 & 0.210 & 5.32 \\
Siltstone & 20 & 0.33 & 0.39 & 0.90 & 0.208 & 4.17 \\
\hline
\end{tabular}

Table 3. Rock mass strength parameters and geological data (Segment 3)

\begin{tabular}{lcccccc}
\hline Rock & $\begin{array}{c}\text { Mean value of } \\
\text { intact comp. } \\
\text { strength, } R_{c}, \mathrm{MPa}\end{array}$ & $\begin{array}{c}\text { Variation } \\
\text { of random } \\
\text { sample, } \eta\end{array}$ & $f(j)$ & $\begin{array}{c}\text { "Corrected" } \\
\text { variation, } \eta^{\prime}\end{array}$ & $\begin{array}{c}\text { Structural } \\
\text { factor, } k_{c}\end{array}$ & $\begin{array}{c}\text { Rock mass } \\
\text { strength, } \\
R_{c}, \mathrm{MPa}\end{array}$ \\
\hline Claystone & 25 & 0.35 & 0.45 & 0.99 & 0.11 & 2.85 \\
Siltstone & 20 & 0.33 & 0.45 & 0.98 & 0.12 & 2.35 \\
\hline
\end{tabular}

Laboratory tests on claystone and siltstone cores, retrieved by the exploratory boreholes, revealed that the intact rock strength varies in $30-35 \%$ with respect to the mean value.

The values of design rock mass strength are necessary components for numerical simulation for each segment. The obtained values show good correlation with corresponding values calculated using GSI system, so they could be applied in finite element method simulation using RocScince software (Hoek, Carter, \& Diederichs, 2013).

\subsection{Numerical (FEM) simulation of the cross-heading advance}

The key indicator of rock mass state is an area of rock failure (area of rock yielding) formed due to the stress redistribution (Khomenko, 2012). A configuration and dimension of the yielding area are the main parameters that cause the support loading. This area should be determined based on adequate strength theory that reflects realistically the rock behavior under given conditions. We use Hoek-Broun failure criterion well proven in geomechanical calculation (Eberhardt, 2012):

$\sigma_{1}=\sigma_{3}+\sqrt{m R_{c} \sigma_{3}+s R_{c}^{2}}$,

where:

$m$ and $s$ - constants depending on the rock mass genesis;

$R_{c}$ - uniaxial compressive strength of the intact rocks that was reduced by the structural factor (1);

$\sigma_{1}$ and $\sigma_{3}$ - major and minor principal stresses at failure (Shah \& Shroff, 2003).

RS3 Rocscince software embodying the well-known finite element method (FEM) is used to simulate three- dimensional rock stress-strain state (Kolosov, Bilous, Tantsura, \& Onyshchenko, 2018) near the cross-heading face and RS2 (PHASE2) is applied to study the twodimensional stress-strain state in plane cross-sections.

Initial stresses are determined considering excavation depth $H=170 \mathrm{~m}$ below the surface and average gravity $\gamma=25 \mathrm{kN} / \mathrm{m}^{3}$. Additional safety factor $K_{\mathrm{s}}=1.8$ should be put into calculation according to (SOU 10.1-00185790002-2005, 2005). It is assumed that the in situ stress field is hydrostatic and the initial stress field is given by the components:

$\left(\sigma_{x}\right)_{0}=\left(\sigma_{y}\right)_{0}=\left(\sigma_{z}\right)_{0}=\gamma \cdot H \cdot K_{s}=7.68 \mathrm{MPa}$.

A three-dimensional analysis carried out under conditions of Segment 1 shows that the total displacements of the cross-heading face are $0.09 \mathrm{~m}$ (Fig. 5) that is less than the displacements in the walls $(0.20-0.22 \mathrm{~m})$ and this suggests that no special measures will be required in order to consolidate the face during excavation, but support should be installed immediately behind the tunnel face. Maximum displacements occur at a distance of $12.5 \mathrm{~m}$ from the face.

Conditions of a plane strain state are embodied there and two-dimensional analysis is appropriate (Bondarenko, Kovalevs'ka, \& Fomychov, 2012). To simulate this effect using the 2-dimensional model, we apply a distributed load to the inside area of the cross-heading boundary, which equals the initial stress distributed along the excavation boundary (in the given case it is $7 \mathrm{MN} / \mathrm{m}^{2}$ ). Then the distributed load gradually decreases through 14 stages up to zero. 
(a)

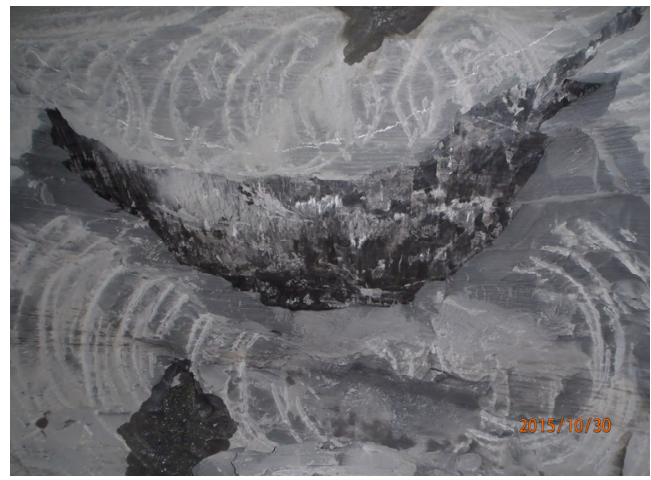

(b)

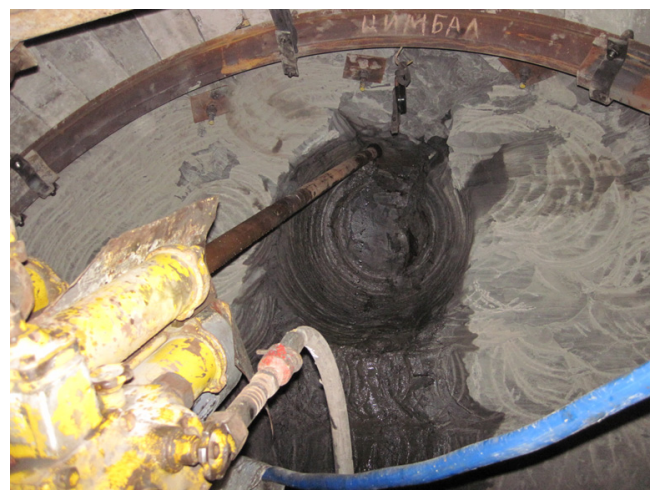

(c)

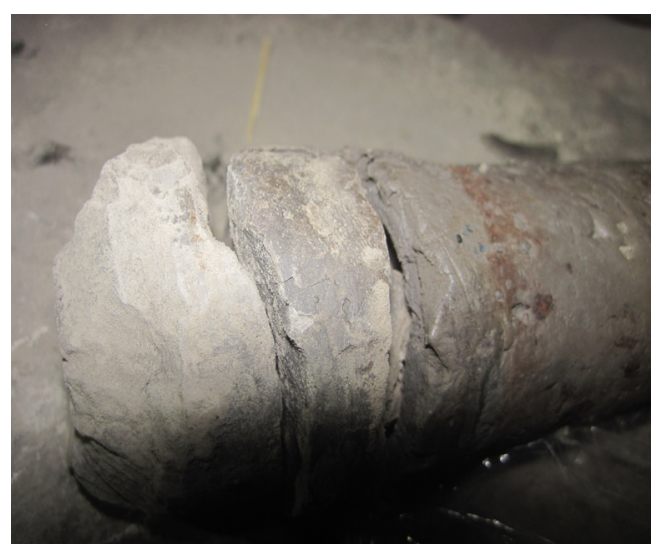

Figure 4. Geology in situ observation and core sampling: (a) visual observation of altered surfaces; (b) water inflow from borehole; c) core with visible joints

The deformation, at which the support is installed, is $20 \%$ of the final deformation. This corresponds to stage 5 (i.e. $80 \%$ of the applied distributed load).

The installation of arched steel support is simulated. A frame metal support shaped like a pavillion (KSHPU) with a wide range of dimensions is the most applicable in Ukraine. Each steel frame has three sections made of a beam of a special cross-section (SVP) and two yielded elements. In the given case we apply the type KSHPU-15 made of beams with SVP-27 profile. The properties of a steel line are defined according to the conception of an "equivalent cross-section" (CarranzaTorres \& Diederichs, 2009).

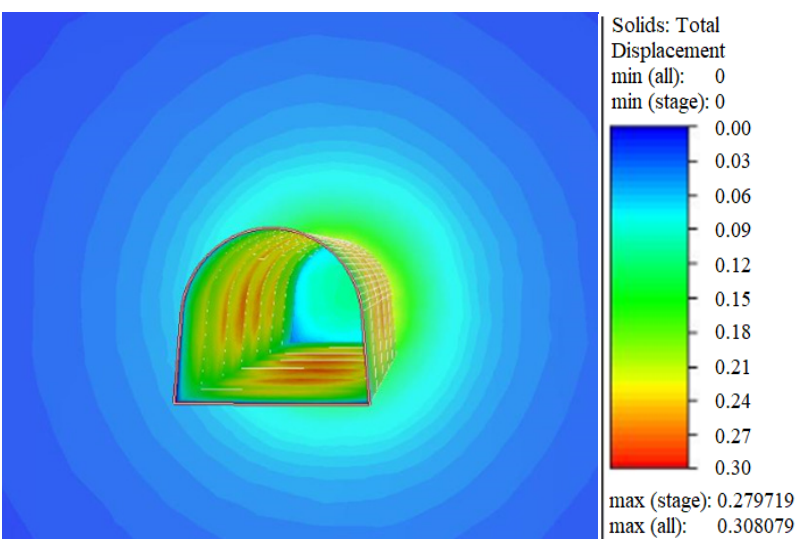

Figure 5. Total displacements depending on a distance from the cross-heading face

Simulating the surrounding rock behavior in Segment 1 gives the height of the yielded zone in the excavation roof in a range of $2.1-2.2 \mathrm{~m}$. Axial force $F$ and bending moment $M$ that occur in the steel line elements are presented in Figure 6. Maximum values are $F_{\max }=0.44 \mathrm{MN} ; M_{\max }=0.025 \mathrm{MN} \cdot \mathrm{m}$. A bearing capacity of the metal line is defined by yielding strength of steel $\left(R_{y}=255-295 \mathrm{MPa}\right.$ for the St. 5 steel grade) and an area of a beam cross-section $\left(S=0.003465 \mathrm{~m}^{2}\right.$ for SVP-27 beam type). Then calculation of critical values of axial force and bending moment for the given type of support yields $F_{c r}=0.88 \mathrm{MN}$ and $M_{c r}=0.028 \mathrm{MN} \cdot \mathrm{m}$ respectively.

Therefore, the support represented only by steel frames is close to exceeding the bearing capacity in terms of bending moments. That is why rockbolts are applied additionally: 9 rockbolts with a length of $2.5 \mathrm{~m}$ are installed along the arch and 2 rockbolts with a length of $1.5 \mathrm{~m}$ reinforce the excavation sides (Kovalevs'ka, Symanovych, \& Fomychov, 2013; Prykhodko \& Ulanova, 2018; Tereshchuk, Khoziaikina, \& Babets, 2018; Bondarenko, Symanovych, Kicki, Barabash, \& Salieiev, 2019).

Ensuring the excavation stability is especially important when the cross-heading face is entering Segment 2, where the rock mass becomes jointed and disintegrated. Analysis shows that the height of the yielded zone in the excavation roof could extend up to $6.0-7.0 \mathrm{~m}$ and displacements could progress up to $0.20-0.26 \mathrm{~m}$, if the support is not reinforced (Fig. 7). That is why the number of steel frames per meter is doubled at this site ( 2 frames per meter).

The load on the support remains very large in this case. This results in the axial force and bending moment in the line elements $F_{\max }=3.07 \mathrm{MN} ; M_{\max }=0.1 \mathrm{MN} \cdot \mathrm{m}$ (Fig. 8) that almost three times exceed the permissible values for given type of the beam profile.

In addition, we should predict that the steel frame installed in jointed and disintegrated rock mass can be loaded irregularly which negatively affects the support stability. We suggest that applying the torcrete provides a more complete contact of the support with the excavation contour. Torcrete mixtures like "Tekhard-T" can be used in a dry process to fill the space between the steel frames and rocks. This ensures stability of the cross-heading while excavating through disintegrated and blocky structures. 
(a)

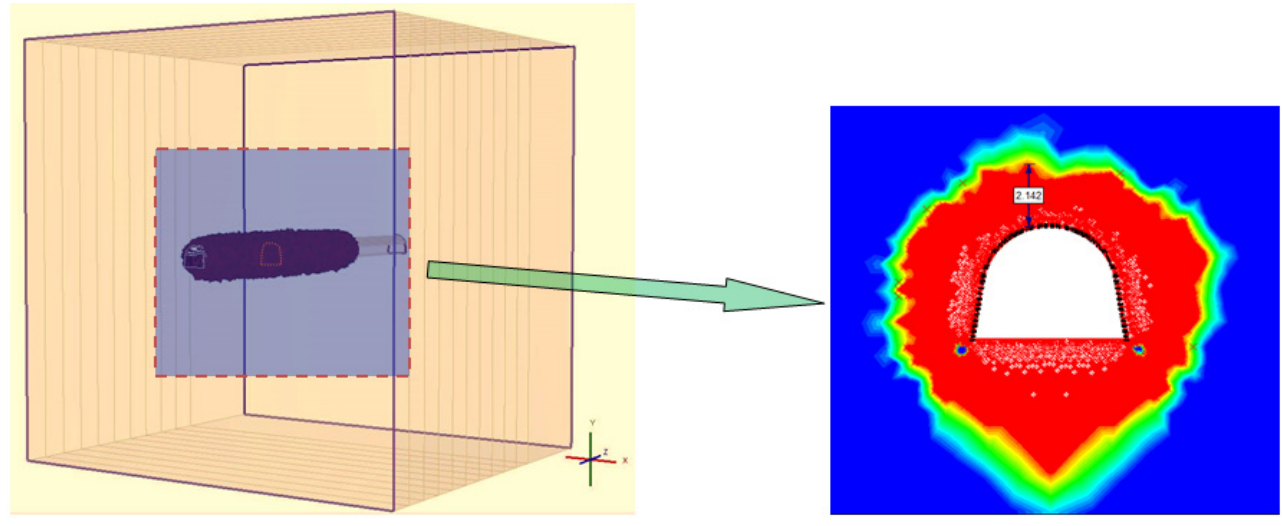

(b)

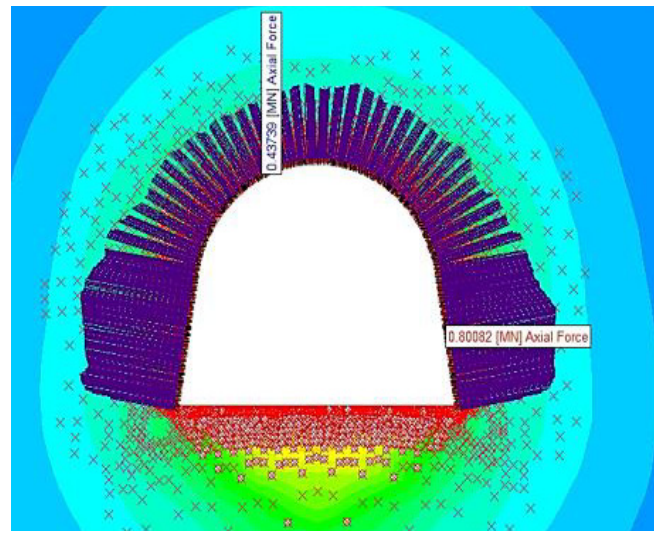

(c)

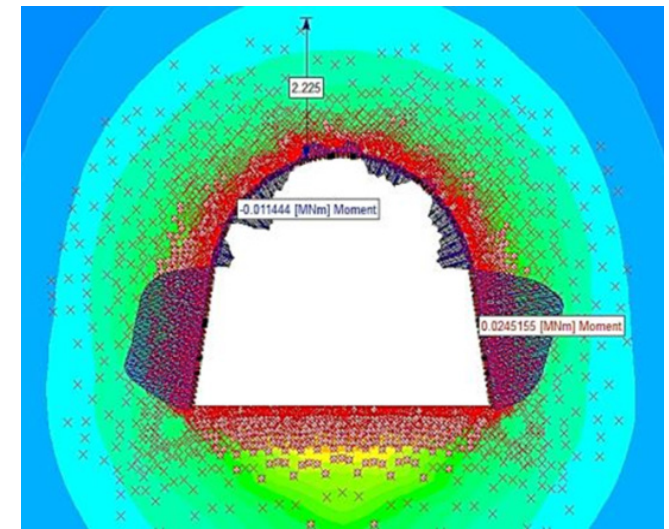

Figure 6. Simulation results concerning Segment 1: (a) yielded area in a plane cross-section; (b) axial force in the steel line; (c) bending moment in the steel line

(a)

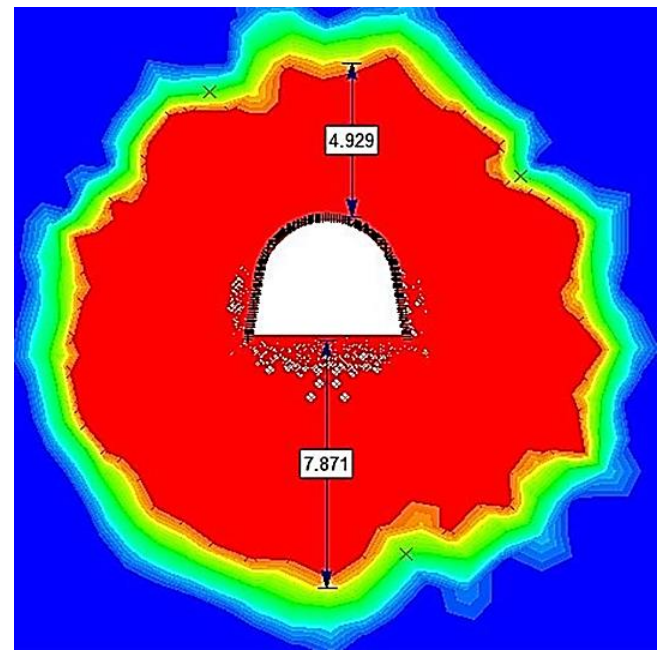

(b)

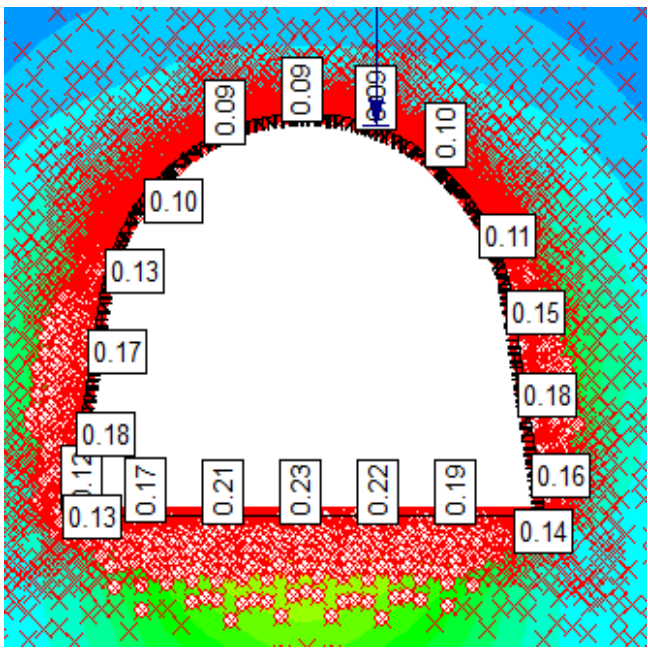

Figure 7. Yielded area and total displacements in case of installation of only steel support without rockbolting in Segment 2: (a) yielded area in a plane cross-section; (b) total displacements on the heading boundary

Besides, steel frames should be installed in rock mass which was previously anchored with rockbolts as it was mentioned above. Simulation of the joint work of the steel line, torcrete layer and rockbolts is carried out in Phase 2 software by introducing a two-layer composite with various layer properties as well as with the appropriate profile dimensions.
Analysis shows (Fig. 9) that rock anchoring and shaping of the torcrete layer reduce the maximum axial force in steel line elements to $1.38 \mathrm{MN}$ (compared with the value of $3.07 \mathrm{MN}$ that takes place in the line element without torcrete application). Maximum bending moment decreases significantly - to $0.058 \mathrm{MN} \cdot \mathrm{m}$, which is 1.7 times less than in the case without torcrete application (compared with the value of $0.1 \mathrm{MN} \cdot \mathrm{m}$ ). 
(a)

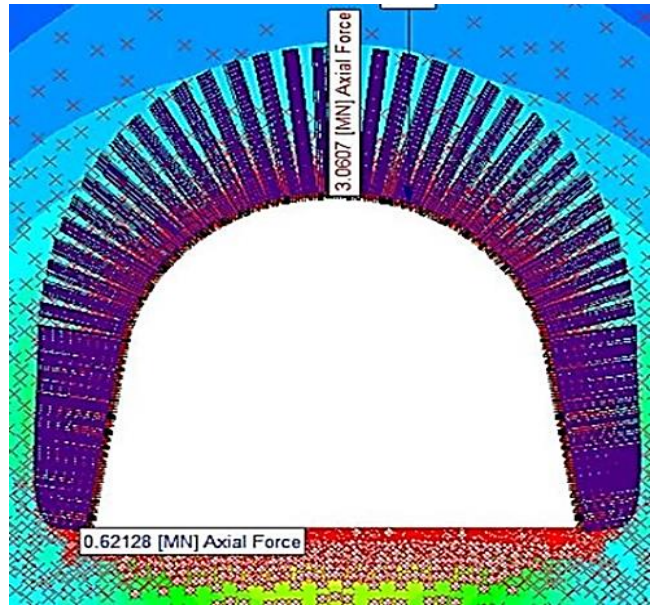

(b)

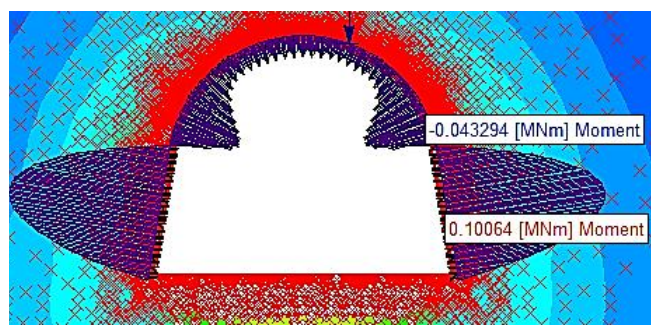

Figure 8. Steel line loading in case of installation of only steel support without rockbolts in Segment 2 \& Segment 4: (a) axial force; (b) bending moment

(a)

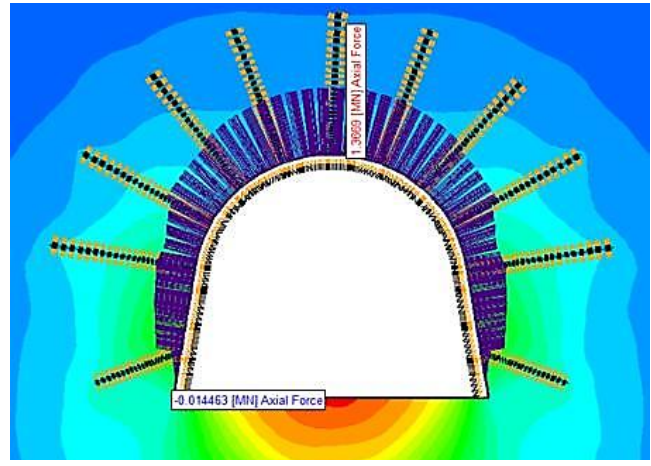

(b)

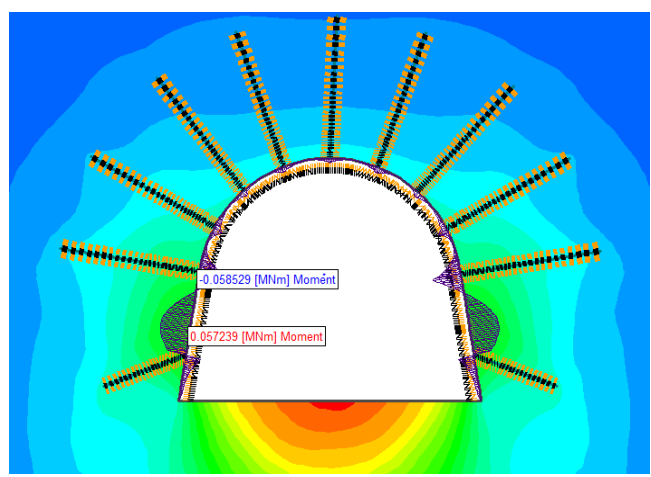

Figure 9. Steel line loading while excavating in Segment 2 in case of installing all the support components: steel frame, torcrete layer and rockbolts: (a) axial force; (b) bending moment
However, despite the positive effect provided by a good contact between the steel line and rock mass, both the axial force and bending moment in line elements exceed the critical values that are permissible for the used kind of a beam profile, so that $F_{\max }=1.57 F_{c r}$; $M_{\max }=2.1 M_{c r}$. That is why additional activities are required to consolidate the disintegrated and sometimes watered rock mass. We suppose that injections of polymer resins reduce the support loading and displacement progressing. A pressure pipe "Irma" with the anchor function intended for the resin injection in rocks provides strengthening of the heavily jointed rocks in the area of $1.2-1.5 \mathrm{~m}$. Two "Irma" anchors are installed in the cross-heading roof while excavating in Segment 2.

When the cross-heading advances and enters the fault zone (Segment 3) the failure (yielded) area in surrounding rocks can extent dramatically up to $9.2 \mathrm{~m}$ in height in the excavation roof and displacements can progress up to $0.6 \mathrm{~m}$ despite the installation of all support components: steel frame, torcrete layer and rockbolts (Fig. 10).

(a)

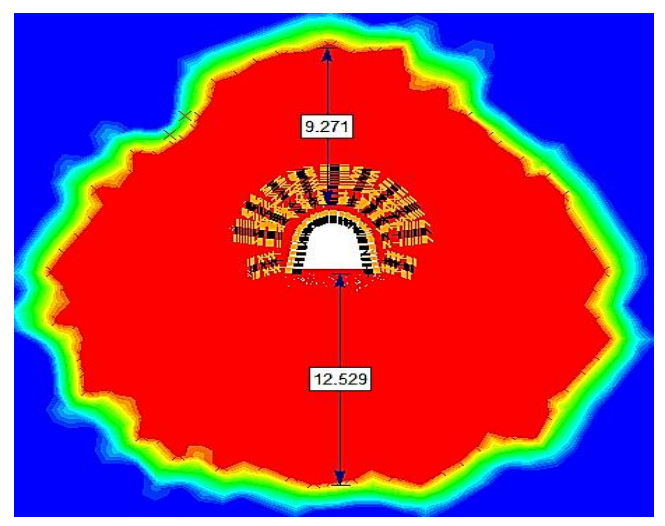

(b)

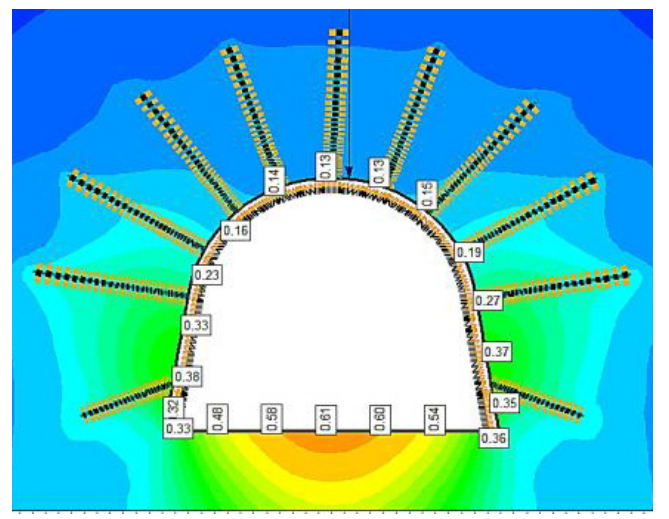

Figure 10. Yielded area and total displacements in case of installation of only steel support without rockbolting in the fault zone: (a) yielded area in a plane cross-section; (b) total displacements on the heading boundary

Considering significant area of failure and extra loading of all support elements in the fault zone, the injection anchors must be installed throughout the contour of the cross-heading including the floor. This creates an area of more consolidated and interlocked mass around the excavation. 
Injection of surrounding rocks provides a reduction in the failure area up to $2.0-2.5 \mathrm{~m}$ and maximum displacements up to $0.05 \mathrm{~m}$ (Fig. 11). Axial force and bending moment in steel lining elements are $F_{\max }=0.67 \mathrm{MN}$ and $M_{\max }=0.025 \mathrm{MN} \cdot \mathrm{m}$ that do not exceed the critical values.

(a)

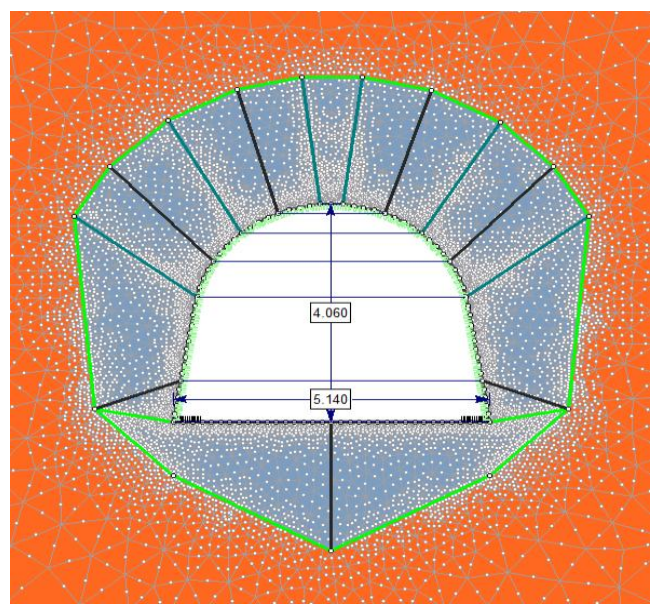

(b)

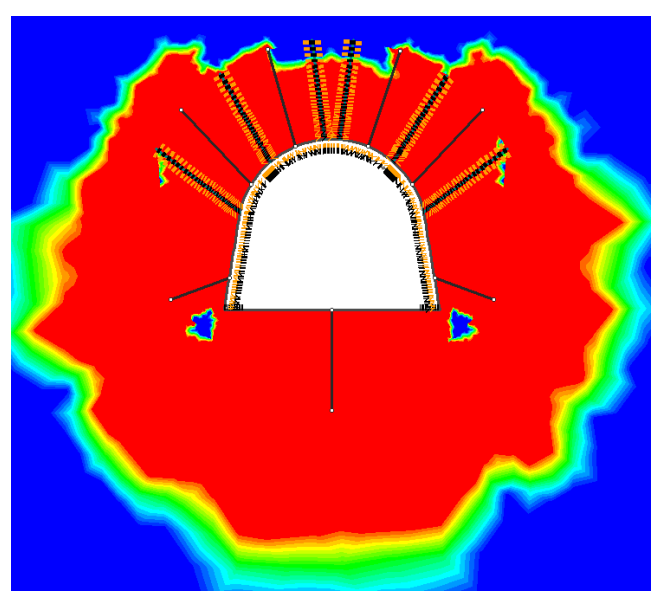

(c)

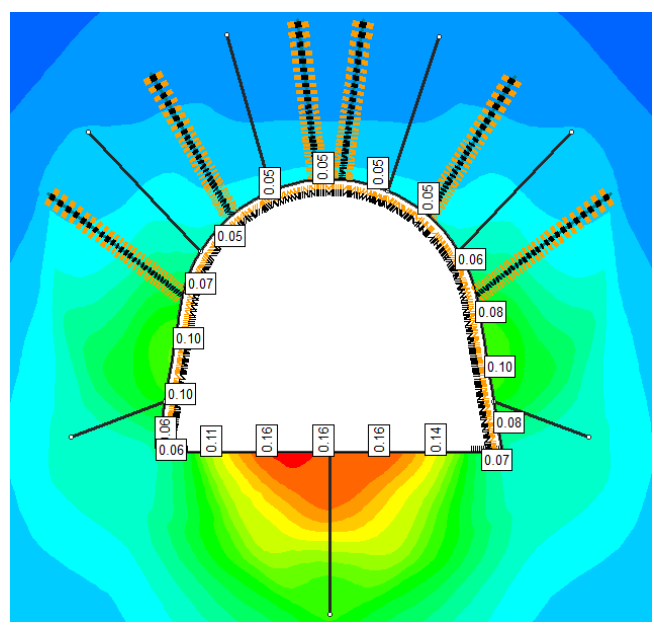

Figure 11. Simulation of the fault zone (Segment 3) after installation of all support components (steel support, torcrete layer, rockbolts) and complete injection of the rock mass around excavation contour: (a) design scheme; (b) yielded area; (c) total displacements

\subsection{Technical features of the project}

The stability of the cross-heading in hazardous area preceding the fault zone is ebsured by the following activities:

1) installing the steel support of KSHPU-15 type with beams of SVP-27 profile and the installation density of 2 frames per meter;

2) installing the anchor system consisting of 9 rockbolts with a length of $2.5 \mathrm{~m}$ fitted along the arch and 2 rockbolts with a length of $1.5 \mathrm{~m}$ installed in the excavation sides;

3) shaping the torcrete layer made in dry process using "Tekhard-T" mixture to fill the space between steel frames and rocks;

4) injecting the excavation roof with two-component polyurethane chemicals "Bevidan-Bevidol" using 2 pressure pipes "Irma" with the anchor function.

The stability of the cross-heading while excavating through the fault zone directly (Segment 3 ) is provided by the activities mentioned above, but in this case the injection anchors must be installed throughout the excavation contour including the floor. This creates an area of more consolidated and interlocked mass around the excavation.

The general view of the supported cross-heading is shown in Figure 12.

Analysis shows that failure area in the excavation floor is even more than in the roof. This means that significant floor heaving should be expected. To prevent the great floor deformation the special construction called "a boot" has been developed. Firstly, the $3 \mathrm{~m}$ long beams are laid on the ground close to the heading walls. Construction represented in Figure 12b is fitted to each steel frame of the support with a locking joint. The base of the "boot" should rest against the underlying beam.

It has been mentioned above that faults present special challenges in excavating because they can lead to sudden and uncontrolled collapses. One of the reasons that can be unforeseen is water pressure behind the face. Unexpected breakdown of water and mud in the heading can turn catastrophic. Therefore, other variants of supporting are discussed in case of the hydrogeological situation deterioration.

\subsection{Monitoring and in situ experience}

We have already mentioned above that the crossheading advance through the fault "Bohdanivskyi" is accompanied by permanent hydrological monitoring. Drilling two probe holes ahead of the advancing face is performed to specify the fault zone borders. One of the holes, $50 \mathrm{~m}$ long, is drilled into the excavation roof at an angle of $45^{\circ}$, and another hole, $45 \mathrm{~m}$ long, is drilled horizontally in the face center at a distance of $1.5 \mathrm{~m}$ from the excavation floor. The volume of return water is monitored during the drilling.

Besides, geomechanical monitoring of the current state of the cross-heading is carried out by visual inspection and instrumental measurements (Małkowski \& Ostrowski, 2019). The following characteristics are recorded at the measuring points: vertical and horizontal convergence; the support state; sliding in the lock yielding elements; the state of the face and surrounding rocks, in particular, block formation, joint propagation, chippings, etc. The water inflow and the release of methane are also fixed. 
(a)

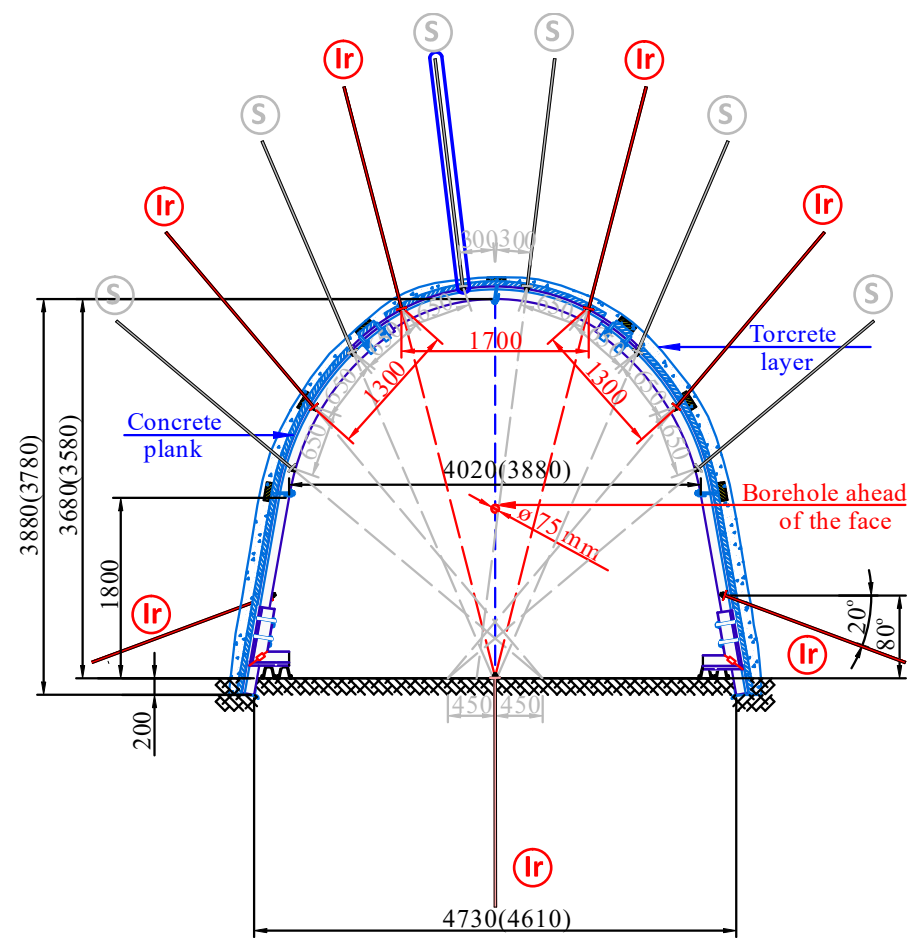

(b)

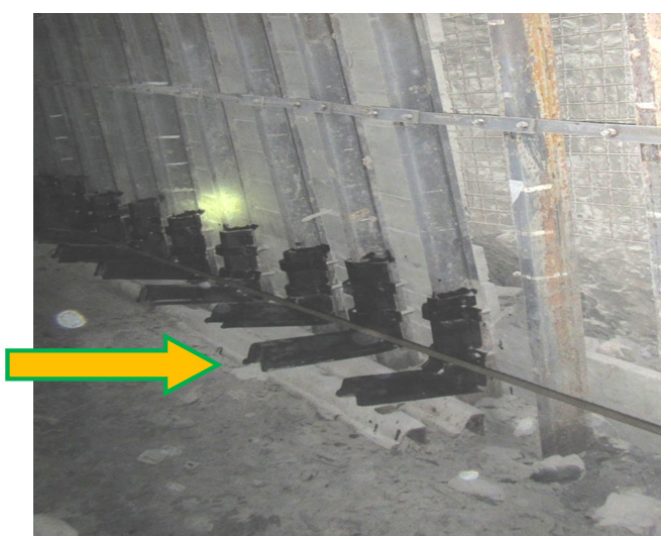

Figure 12. Support design developed for the cross-heading (KSHPU-15): (a) combination of support systems; (b) construction called "a boot" to prevent floor heaving

During the entire period of the cross-heading excavation and monitoring, there were no critical states that could result in uncontrolled deformations and collapse. Experience of the cross-heading excavating through the fault "Bohdanivskyi" can be considered successful. Statistical data concerning rock displacements around the excavation were accumulated and processed according to the developed technique (Shcherbakov, Klymenko, \& Tymchenko, 2017; Kirichenko, Kulivar, Skobenko, \& Khalymendyk, 2019). The histogram in Figure 13 shows, that the decrease in the height and width of the crossheading along the entire route of its driving does not exceed $0.03 \mathrm{~m}$. This means that all technological measures and activities are justified sufficiently.

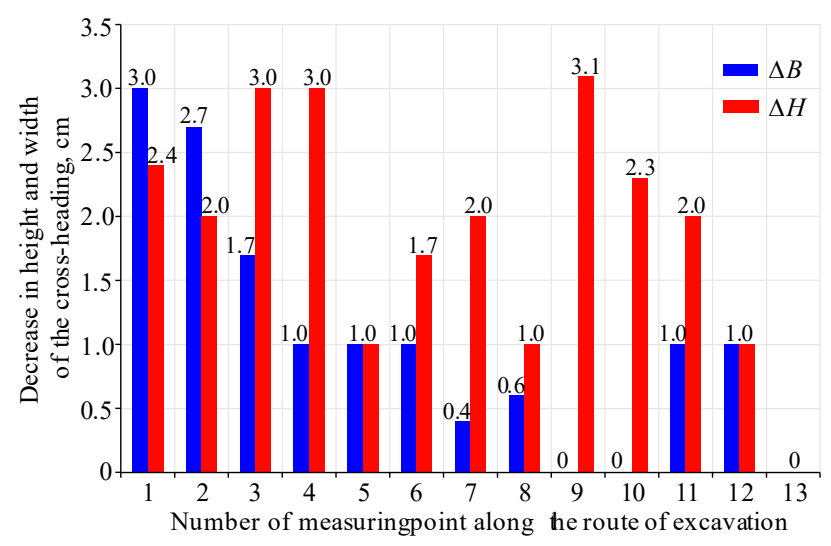

Figure 13. Decrease in the cross-heading height and width along the entire route of driving: $\Delta H, \Delta B$ are reductions in height and width respectively

\section{CONCLUSIONS}

1. Excavating a cross-heading through the fault "Bohdanivskyi" presents a special challenge because the rock displacements can progress dramatically due to excessive overload and ground water inflows. The lack of information concerning the material structure in the fault zone and complexity of hydrogeological conditions aggravates the problem.

2. Lack of experience in excavating through the fault zones has given a particular urgency to the simulation of geomechanical processes as the most secure and inexpensive method for predicting rock behavior in hazardous areas.

3. The technique of rock mass strength estimation using structural factor based on statistical strength theory was implemented to improve adequacy of mathematical modeling.

4. Numerical simulation based on finite element method provided the adequate support design.

5. The cross-heading stable state in hazardous area preceding the fault zone is provided by installing the steel support of KSHPU-15 type with beams of SVP-27 profile and the installation density of 2 frames per meter; installing the anchor system consisting of 9 rockbolts with a length of $2.5 \mathrm{~m}$ fitted along the arch and 2 rockbolts $1.5 \mathrm{~m}$ long installed in the excavation sides; shaping the torcrete layer made in dry process using the "Tekhard-T" mixture to fill the space between steel frames and rocks as well as injecting the excavation roof with two-component Polyurethane Chemicals "BevidanBevidol" using 2 pressure pipes "Irma" with the anchor function. The stable state of the cross-heading while excavating directly through the fault zone is provided by the activities mentioned above, but in this case injection 
anchors must be installed throughout the excavation contour including the floor. This creates an area of more consolidated and interlocked mass around the excavation.

\section{ACKNOWLEDGEMENTS}

This work was supported by PJS Company "DTEK Pavlohradvuhillia", grants No. 050420/372-PU-SHUTr. The authors would like to thank all technical staff of the mine "Samarska" for the help during the in situ observation.

\section{REFERENCES}

Babets, D. (2018). Rock mass strength estimation using structural factor based on statistical strength theory. Solid State Phenomena, (277), 111-122.

https://doi.org/10.4028/www.scientific.net/SSP.277.111

Babets, D.V., Sdvyzhkova, O.O., Larionov, M.H., \& Tereshchuk, R.M. (2017). Estimation of rock mass stability based on probability approach and rating systems. Naukovyi Visnyk Natsionalnoho Hirnychoho Universytetu, (2), 58-64.

Bomba, A., Tkachuk, M., Havryliuk, V., Kyrysha, R., Gerasimov, I., \& Pinchuk, O. (2018). Mathematical modelling of filtration processes in drainage systems using conformal mapping. Journal of Water and Land Development, 39(1), 11-15. https://doi.org/10.2478/jwld-2018-0054

Bondarenko, V., Kovalevs'ka, I., \& Fomychov, V. (2012). Features of carrying out experiment using finite-element method at multivariate calculation of "mine massif - combined support" system. Geomechanical Processes During Underground Mining - Proceedings of the School of Underground Mining 2012, 7-13. https://doi.org/10.1201/b13157-3

Bondarenko, V., Symanovych, H., Kicki, J., Barabash, M., \& Salieiev, I. (2019). The influence of rigidity of the collapsed roof rocks in the mined-out space on the state of the preparatory mine workings. Mining of Mineral Deposits, 13(2), 27-33.

https://doi.org/10.33271/mining13.02.027

Bondarenko, V.I., Kharin, Ye.N., Antoshchenko, N.I., \& Gasyuk, R.L. (2013). Basic scientific positions of forecast of the dynamics of methane release when mining the gas bearing coal seams. Naukovyi Visnyk Natsionalnoho Hirnychoho Universytetu, (5), 24-30.

Carranza-Torres, C. \& Diederichs, M. (2009). Mechanical analysis of circular liners with particular reference to composite supports. For example, liners consisting of shotcrete and steel sets. Tunneling and Underground Space, 24(5), 506-532.

Dychkovskyi, R.O., Lozynskyi, V.H., Saik, P.B., Petlovanyi, M.V., Malanchuk, Y.Z., \& Malanchuk, Z.R. (2018). Modeling of the disjunctive geological fault influence on the exploitation wells stability during underground coal gasification. Archives of Civil and Mechanical Engineering, 18(4), 1183-1197. https://doi.org/10.1016/j.acme.2018.01.012

Eberhardt, E. (2012). The Hoek-Brown failure criterion. Rock Mechanics and Rock Engineering, 45(6), 981-988. https://doi.org/10.1007/s00603-012-0276-4

Hahn, J., \& Shapiro, S. (1994). Statistical models in engineering. New York, United States: John Wiley \& Sons.

Hoek, E. (2002). Practical rock engineering. London, United Kingdom: Institution of Mining and Metallurgy.

Hoek, E., Carter, T.G., \& Diederichs, M.S. (2013). Quantification of the geological strength index chart. Proceedings of the $47^{\text {th }}$ US Rock Mechanics, 1-8.

Khalymendyk, I., \& Baryshnikov, A. (2018). The mechanism of roadway deformation in conditions of laminated rocks. Journal of Sustainable Mining, 17(2), 41-47. https://doi.org/10.1016/i.jsm.2018.03.004
Khomenko, O.Ye. (2012). Implementation of energy method in study of zonal disintegration of rocks. Naukovyi Visnyk Natsionalnoho Hirnychoho Universytetu, (4), 44-54.

Kirichenko, A., Kulivar, S., Skobenko, A., \& Khalymendyk, O. (2019). A technique to measure sensitivity of explosives to the effect of laser pulse radiation. Naukovyi Visnyk Natsionalnoho Hirnychoho Universytetu, (4), 36-40. https://doi.org/10.29202/nvngu/2019-4/2

Kolosov, D., Bilous, O., Tantsura, H., \& Onyshchenko, S. (2018). Stress-strain state of a flat tractive-bearing element of a lifting and transporting machine at operational changes of its parameters. Solid State Phenomena, (277), 188-201. https://doi.org/10.4028/www.scientific.net/ssp.277.188

Kovalevs'ka, I., Symanovych, G., \& Fomychov, V. (2013). Research of stress-strain state of cracked coal-containing massif near-the-working area using finite elements technique. Annual Scientific-Technical Collection - Mining of Mineral Deposits 2013, 159-163. https://doi.org/10.1201/b16354-28

Law, B.E., Ulmishek, G.F., Clayton, J.L., Kabyshev, B.P., Pashova, N.T., \& Krivosheya, V.A. (1998). Basin-centered gas evaluated in Dnieper-Donets basin, Donbas foldbelt, Ukraine. Oil and Gas Journal, 96(47), 74-78.

Małkowski, P., \& Ostrowski, L. (2019). Convergence monitoring as a basis for numerical analysis of changes of rockmass quality and Hoek-Brown failure criterion parameters due to longwall excavation. Archives of Mining Sciences, 68(1), 93-118. https://doi.org/10.24425/ams.2019.126274

Marinos, P., \& Hoek, E. (2000). GSI - A geologically friendly tool for rock mass strength estimation. Conference Proceedings - GeoEng 2000, 1422-1446.

Nadutyi, V., Tytov, O., \& Cheberiachko, I. (2018). Hereditary model of loose mined rock layer deformation in disintegrators. E3S Web of Conferences, (60), 00033. https://doi.org/10.1051/e3sconf/20186000033

Nahornyi, Yu.M., Nahornyi, V.M., \& Prykhodchenko, V.F. (2005). Heolohiia vuhilnykh rodovysh. Dnipropetrovsk, Ukraina: Natsionalnyi Hirnychyi Universytet.

Olevskyi, V., \& Olevska, Y. (2018). Mathematical model of elastic closed flexible shells with nonlocal shape deviations. Journal of Geometry and Symmetry in Physics, 57-69. https://doi.org/10.7546/jgsp-50-2018-57-69

Pivnyak, G., Dychkovskyi, R, Bobyliov, O., Cabana, C.E., \& Smoliński, A. (2018). Mathematical and geomechanical model in physical and chemical processes of underground coal gasification. Solid State Phenomena, (277), 1-16. https://doi.org/10.4028/www.scientific.net/SSP.277.1

Pivnyak, G., Dychkovskyi, R., Smirnov, A., \& Cherednichenko, Yu. (2013). Some aspects on the software simulation implementation in thin coal seams mining. Energy Efficiency Improvement of Geotechnical Systems - Proceedings of the International Forum on Energy Efficiency, 1-10.

Pivnyak, G.G., \& Shashenko, O.M. (2015). Innovations and safety for coal mines in Ukraine. Naukovyi Visnyk Natsionalnoho Hirnychoho Universytetu, (6), 118-121.

Prykhodchenko, V.F., Sdvyzhkova, O.O, Khomenko, N.V., \& Tykhonenko, V.V. (2016). Effect of time-transgressive faults upon methane distribution within coal seams. Naukovyi Visnyk Natsionalnoho Hirnychoho Universytetu, (1), 31-35.

Prykhodko, V., \& Ulanova, N. (2018). Modeling of stressstrain state of fractured rock mass nearby of conjugated workings. Naukovyi Visnyk Natsionalnoho Hirnychoho Universytetu, (1), 5-12. https://doi.org/10.29202/nvngu/2018-1/15

Sdvyzhkova, O., Babets, D., Kravchenko, K., \& Smirnov, A. (2015). Rock state assessment at initial stage of longwall mining in terms of poor rocks of Western Donbass. New 
Developments in Mining Engineering 2015: Theoretical and Practical Solutions of Mineral Resources Mining, 65-70. https://doi.org/10.1201/b19901-13

Sdvyzhkova, O.O., Babets, D.V., \& Smirnov, A.V. (2014). Support loading of assembly chamber in terms of Western Donbas plough longwall. Naukovyi Visnyk Natsionalnoho Hirnychoho Universytetu, (5), 26-32.

Shah, D.L., \& Shroff, A.V. (2003). Soil mechanics and geotechnical engineering. London, United Kingdom: CRC Press.

Shashenko, A., Gapieiev, S., \& Solodyankin, A. (2009). Numerical simulation of the elastic-plastic state of rock mass around horizontal workings. Archives of Mining Sciences, 54(2), 341-348.

Shcherbakov, P., Klymenko, D., \& Tymchenko, S. (2017). Statistical research of shovel excavator performance during loading of rock mass of different crushing quality. Naukovyi Visnyk Natsionalnoho Hirnychoho Universytetu, (1), 49-54.

Solodyankin, O., Hryhoriev, O., Dudka, I., \& Mashurka, S. (2017). Criterion to select rational parameters of supports to reduce expenditures connected with construction and maintenance of development working. Naukovyi Visnyk Natsionalnoho Hirnychoho Universytetu, (2), 19-27.

SOU 10.1-00185790-002-2005. Rules of technical operation in coal mines. (2005). Kyiv, Ukraine: Minvuhleprom Ukrainy.

Tereshchuk, R.M., Khoziaikina, N.V., \& Babets, D.V. (2018). Substantiation of rational roof-bolting parameters. Naukovyi Visnyk Natsionalnoho Hirnychoho Universytetu, (1), 19-26. https://doi.org/10.29202/nvngu/2018-1/18

Tytov, O., Haddad, J., \& Sukhariev, V. (2019). Modelling of mined rock thin layer disintegration taking into consideration its properties changing during compaction. E3S Web of Conferences, (109), 00105. https://doi.org/10.1051/e3sconf/201910900105

Vladyko, O., Kononenko, M., \& Khomenko, O. (2012). Imitating modeling stability of mine workings. Geomechanical Processes during Underground Mining, 147-150. https://doi.org/10.1201/b13157-26

Zhang, R., Jiang, Z., Zhou, H., Yang, C., \& Xiao, S. (2013). Groundwater outbursts from faults above a confined aquifer in the coal mining. Natural Hazards, 71(3), 1861-1872. https://doi.org/10.1007/s11069-013-0981-7

\section{РЕАЛІЗАЦІЯ ІМОВІРНІСНОГО ПІДХОДУ ДО ОЦІНКИ МІЦНОСТІ ГІРСЬКИХ ПОРІД ПРИ ПЕРЕТИНІ ЗОНИ ВЕЛИКОГО ГЕОЛОГІЧНОГО ПОРУШЕННЯ}

\section{Д. Бабець, О. Сдвижкова, О. Шашенко, К. Кравченко, Е.К. Кабана}

Мета. Стаття спрямована на оцінку стану породного масиву при проведенні відкаточного квершлагу через зону великого регіонального геологічного порушення “Богданівський” скид на основі ймовірнісного підходу до оцінки міцності гірських порід.

Методика. Межі зони геологічного порушення визначалися із використанням бази даних геологічної служби. Значення очікуваного водотоку та наявність метану визначалися із використанням методу пробного буріння попереду вибою. Для оцінки міцності гірських порід використана статистична теорія міцності. Чисельне моделювання проводилося з використання добре апробованого в задачах геомеханіки методу скінченних елементів.

Результати. Методика оцінки міцності масиву гірських порід, що заснована на статистичній теорії міцності, була використана для підвищення адекватності математичного моделювання. Виконано чисельне моделювання геомеханічних процесів на основі методу скінченних елементів і критерію міцності Хока-Брауна. Визначено зміни напружено-деформованого стану порід при проведенні відкаточного квершлагу через різні ділянки зони геологічного порушення в залежності від ступеню дезінтеграції порід.

Наукова новизна. Встановлено нові закономірності поведінки породного масиву в зоні геологічного порушення на основі оцінки міцності порід, що враховує ступінь дезінтеграції й обводнення породного масиву.

Практична значимість. Адекватна оцінка міцності породного масиву і ступеня його зрушеності дозволила розробити комбіноване кріплення, що включає металеву арку, анкерну систему та шар торкретбетону.

Ключові слова:зона геологічного порушення, кріплення, коефіџієнт структурного ослаблення, тріщинуватість, міцність породного масиву

\section{РЕАЛИЗАЦИЯ ВЕРОЯТНОСТНОГО ПОДХОДА К ОЦЕНКЕ ПРОЧНОСТИ ГОРНЫХ ПОРОД ПРИ ПЕРЕСЕЧЕНИИ ЗОНЫ КРУПНОГО ГЕОЛОГИЧЕСКОГО НАРУШЕНИЯ}

\section{Д. Бабец, Е. Сдвижкова, А. Шашенко, К. Кравченко, Э.К. Кабана}

Цель. Статья направлена на оценку состояния породного массива при проведении откаточного квершлага через зону крупного регионального геологического нарушения "Богдановский” сброс на основе вероятностного подхода к оценке прочности горных пород.

Методика. Границы зоны геологического нарушения определялись с использованием базы данных геологической службы. Значения ожидаемого водопритока и наличие метана определялись с использованием метода пробных бурений, выполняемых впереди забоя выработки. Для оценки прочности горных пород использована статистическая теория прочности. Численное моделирование выполнено с использованием метода конечных элементов, хорошо апробированного в задачах геомеханики.

Результаты. Методика оценки прочности массива горных пород, основанная на статистической теории прочности, применена с целью повышения адекватности математического моделирования. Выполнено численное моделирование геомеханических процессов на основе метода конечных элементов и критерия прочности Хока-Брауна. Определены изменения напряженно-деформированного состояния пород при проведении откаточного квершлага через различные участки зоны геологического нарушения в зависимости от степени дезинтеграции пород. 
Научная новизна. Установлены новые закономерности поведения породного массива в зоне геологического нарушения на основе оценки прочности пород, учитывающей степень дезинтеграции и обводнения породного массива.

Практическая значимость. Адекватная оценка прочности породного массива и степени его нарушенности позволила разработать комбинированную крепь, включающую металлическую арку, анкерную систему и слой торкретбетона.

Ключевые слова: зона геологического нарушения, крепь, коэффищиент структурного ослабления, трещиноватость, прочность породного массива

\section{ARTICLE INFO}

Received: 6 November 2018

Accepted: 22 October 2019

Available online: 5 November 2019

\section{ABOUT AUTHORS}

Dmytro Babets, Candidate of Technical Sciences, Professor of the Higher Mathematics Department, Dnipro University of Technology, 19 Yavornytskoho Ave., 49005, Dnipro, Ukraine. E-mail: babets.d.v@nmu.one

Olena Sdvyzhkova, Doctor of Technical Sciences, Head of the Higher Mathematics Department, Dnipro University of Technology, 19 Yavornytskoho Ave., 49005, Dnipro, Ukraine. E-mail: sdvyzhkova.o.o@nmu.one

Oleksandr Shashenko, Doctor of Technical Sciences, Professor of the Department of Construction, Geotechnics and Geomechanics, Dnipro University of Technology, 19 Yavornytskoho Ave., 49005, Dnipro, Ukraine. E-mail: shashenko.o.m@nmu.one

Kostiantyn Kravchenko, Candidate of Technical Sciences, Associate Professor of the Department of Construction, Geotechnics and Geomechanics, Dnipro University of Technology, 19 Yavornytskoho Ave., 49005, Dnipro, Ukraine. E-mail: kravchenko.k.v@nmu.one

Edgar Cáceres Cabana, Candidate of Technical Sciences, Center of Renewable Energy and Energy Efficiency, University of St. Augustine, 117 Calle Santa Catalina, 4100, Arequipa, Peru. E-mail: ecaceresca@unsa.edu.pe 